\title{
ランチョンセミナー(20)＼cjkstart頭頸部癌に対する免疫療法を含めた シークエンス治療
}

門田 伸也

四国がんセンター＼cjkstart頭頸科・甲状腺腫瘍科

2013年に抗 EGFR 抗体であるセツキシマブが頭頸部癌に対して保険承認され、局所進行頭頸部がんに対する BRT (bio-radiotherapy）や再発転移頭頸部癌に対する EXTREME レジメンが臨床に導入されて現在に至っている。

局所進行頭頸部癌に対しては BRT と標準治療である CRT (chemo-radiotherapy) との効果比較について検証がなさ れてきた。その過程でむしろ CDDP 併用 CRT の有効性が再認識され、十分な投与総量の大切さがクローズアップされ るとともにその有害事象についても改めて注目が集まっている。一方で、腫瘍のリスクに応じて、治療効果と有害事象 軽減のバランスをとるという選択肢も模索されてきた。その候補として、De-ESCALaTE 試験と RTOG1016 試験の結 果が2018年末に公表された。これらの試験は HPV 陽性中咽頭がんを対象とした CDDP併用 CRT と BRT の効果を直接 比較した第III相 RCT である。De-ESCALaTE 試験のプライマリーエンドポイントは毒性比較であり、OS や局所制御も あわせて検証された。一方、RTOG1016 試験におけるプライマリーエンドポイントは 5 年 OS であり、BRT 群のCRT 群に対する非劣性を示すことを目的とした。これらの試験結果いかんでは比較的予後が良いとされる HPV 陽性中咽頭 がんに対して有害事象の軽減につながる治療オプションと期待された。しかし、両試験ともに治療効果・有害事象とも にCRT 群が勝る結果となった。

再発転移頭頸部がんに対する全身治療の第一選択肢は EXTREME レジメン $(\mathrm{CDDP}+5-\mathrm{FU}+$ セツキシマブ）とされ ている。しかし、2015年に抗 PD-1 抗体であるニボルマブが頭頸部癌に対しても保険承認がなされた。現時点ではその 有効性を示した Checkpoint141 試験に準じてプラチナ耐性あるいはプラチナ不応の症例に対する二次治療として適用さ れているが、治療法の組み合わせや順序については現在も議論がなされている。

さらに2018年に Keynote 048 試験の結果が報告された。再発転移頭頸部癌に対する一次治療として抗 PD-1 抗体であ るペンプロリズマブ群が EXTREME 群に OS で優位であったことから、ある特定の条件下では免疫チェックポイント 阻害薬が一次標準治療となり得ることが示された。たたし、今後この報告の詳細についてよく検証する必要があろう。

図はセツキシマブの NK 細胞を介する ADCC 活性とそこから誘導された免疫抑制機構を模式化した図である。

PD-L1 はセツキシマブ治療のみならず、多くの化学療法や放射線治療によっても誘導されることから化学療法、放 射線治療、分子標的薬治療に免疫チェックポイント阻害薬治療をうまく組み合わせていくシークエンス治療の考えが発 展していくことが予想される。

本講演では最近のトピックとなる報告を検証しながら、今後の分子標的薬治療について考察を行う。

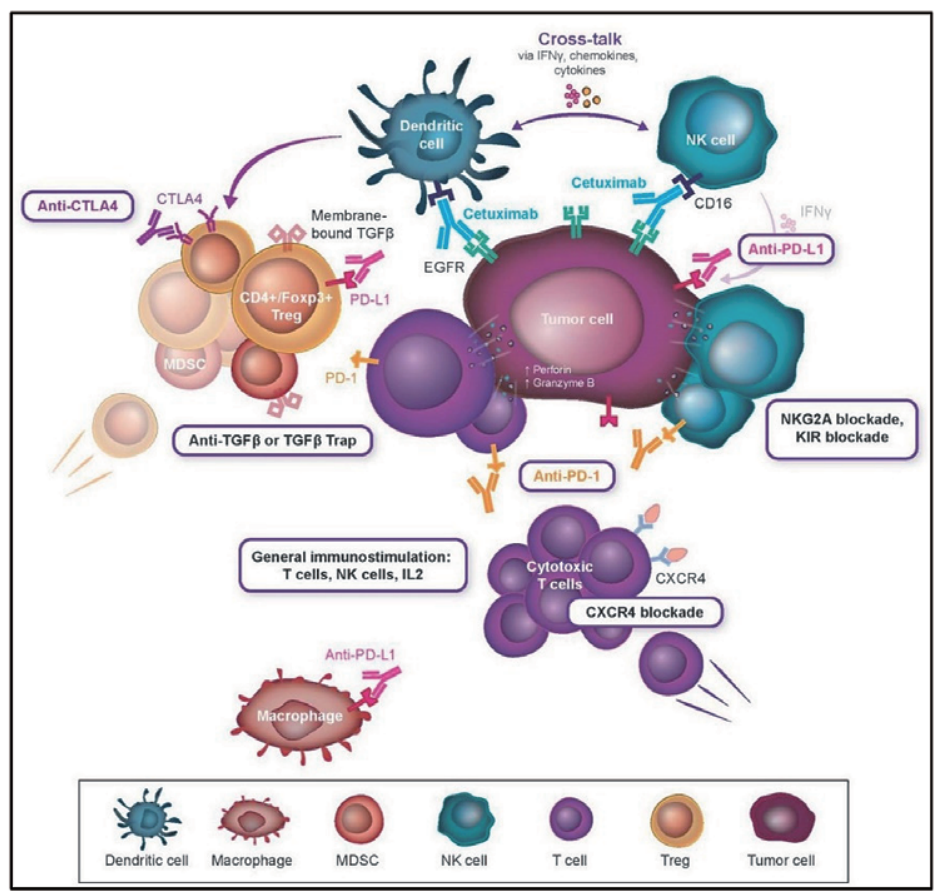

図 1 R.L. Ferris, et al: Cancer Treatment Reviews 2018；63：48-60より。 